\title{
Economics of Onion Production in Sikar District of Rajasthan, India
}

\author{
Swati Sharma* \\ ASPEE Agribusiness Management Institute, Navsari Agricultural University, Navsari, India \\ *Corresponding author
}

\section{A B S T R A C T}

\begin{tabular}{|l|}
\hline K e y w o r d s \\
Onion, Production, \\
Costs, Returns \\
\hline Article Info \\
\hline $\begin{array}{l}\text { Accepted: } \\
\text { 12 June } 2019 \\
\text { Available Online: } \\
\text { 10 July } 2019\end{array}$ \\
\hline
\end{tabular}

The Onion is the major vegetable crop of Rajasthan. The study was conducted in Sikar district of Rajasthan, where onion is an important crop. A sample of 75 onion growers, based on land holding size were selected viz., small, semi-medium, medium and large size. the average area, production and productivity of Sikar district in the last 30 years (1981 to 2010) were observed 2618.9 hectares, 25075.9 tons and 95.7 q /ha, respectively. In Sikar district area, production and productivity of onion in the overall period (1981-2010) have increased by $6.71,8.11$ and 1.32 per cent per annum. Production of onion in this period has increased due to increase in both the area and productivity but the maximum contribution was observed by the area. The average bulb yield of onion was obtained by the small, semi-medium, medium and large farmers was 267.2, 275.1, 286.1 and $310.6 \mathrm{q} / \mathrm{ha}$, respectively. Total onion bulb yield was produced by all 75 onion growers was $13584.72 q$ from the 46.25 ha area. On an average, total cost (cost $\left.\mathrm{C}_{2}\right)$ incurred in cultivation of onion was Rs.43263.3 per hectare. The total cost incurred in cultivation of onion was highest on small followed by semi-medium, large and medium sized farms. The operational cost in cultivation of onion was highest on small sized farms and lowest on large sized farms. The overhead cost in cultivation of onion was highest on large sized farms followed by small, semi-medium and medium sized farms. The cost of production per quintal of onion was highest on small and lowest on large sized farms. The study concluded that the large size group of farms obtained the largest amount of profit in the study area. The results further revealed that the income measures viz., gross return, return over operating cost, net return, family labour income and farm business income were highest on large sized farms followed by medium, semi-medium and small sized farms in the Sikar district.

\section{Introduction}

The onion (Allium cepa L.) is one of the most important vegetable crops grown in the entire world. Globally onions are grown in an area of 4.45 million hectare with a production of 85.94 million tonnes of an average productivity of $19.30 \mathrm{t} / \mathrm{ha}$. In India production of onion has increased from 40.4 lakh tonnes
(1994-95) to 215.63 lakh tonnes (2016-17), India ranks first by area (12.71 lakh hectare) in onion and second in production (215.63 lakh tonnes) next to China, but productivity is 16.1 tonnes hectare which is low as compared to Netherland, USA, China and the other countries. During 2016-17 India exported 34.93 lakh tonnes of onion (Anonymous, 2017). The reason for low productivity may be 
due to majority of Indian varieties are short day type which yields low per unit area, whereas long day types onion yields are high per unit area since prevailing of long crop duration, which are not suited for major onion growing areas of India except hilly regions where long day falls (Manjunathagowda et al., 2015). The major onion producing states in the country are Maharashtra, Karnataka, Gujarat, Bihar, Madhya Pradesh, Andhra Pradesh, Rajasthan, Haryana, Uttar Pradesh and Tamil Nadu. These states together account about 87.93 per cent of the total area and 89.91 per cent of the total production of onion in the country (Anonymous, 2010). Onion in the country is planted in three season's viz., kharif, late kharif and rabi with 20, 20 and $60 \%$ proportion, respectively.

The growing demand for onions induced by rising income and changing consumption patterns coupled with declining farm incomes due to rising costs and stagnating food grain productivity has necessitated diversification towards high-value crops in recent times in Sikar district of Rajasthan. Apart from income enhancement, this high-value crop has potential to generate additional employment opportunities in farming due to their labourintensive character (Weinberger and Lumpkin, 2006). Thus, to improve income, provide gainful employment and save natural resources from further degradation, diversification from grain crops to high-value crops like onion vegetable has emerged as an important strategy for agricultural growth (Sekhon and Kaur, 2004). The fluctuations in production of onion adversely affect the employment and income distribution and hamper the economic growth of the state. The overtime increase in the cost of production and prices of onion have affected the profitability of onion producers. Hence, there is needed to study the input use, cost structure and profitability of onion on different size group of farms. There are only few prominent studies were under taken, which have covered the cost of production, marketing and constraints aspects and analyses various factors affecting its profitability to the producer and intermediaries in the sale of onion is available (Dangat et al., 1989; Mishra et al., 1995; Shyamasunder and Achoth 1996; Mohapatra 1999; Shah 1999; Verma et al., 2004).

The present investigation was under taken with the following objectives:

To work out the growth rate in area, production and productivity of onion.

To study the economics of production of onion on the farms of different size-groups.

\section{Materials and Methods}

The study was conducted in Sikar district of Rajasthan, where onion is an important crop. A sample of 10 villages was selected in the three tehsils having highest cultivated area of onion in Sikar district. Further, a sample of 75 farmers was taken from the selected onion producing villages. The onion producing farmers were then categorized as small (0-2 ha) semi-medium (2-4 ha), medium (4-10 ha) and large size (>10.0 ha), based on land holding size of the farmers in each selected district. The farmers to be selected from each village were distributed among these four categories in proportion to the number of farmers in each category. The number of selected onion producing farmers was in 16 in small, 28 in semi-medium, 19 in medium and 12 in large category. The study utilized both secondary and primary data, to fulfill the objectives of the present study. To study the growth rate in area, production and productivity, of Sikar district, time series data on area, production and productivity of onion were collected for the period from 1981 to 2010 from the Statistical Cell, 
Commissionerate of Agriculture Rajasthan, Jaipur. The primary data regarding cost of cultivation, fixed assets, yield returns of production was collected from the sample farmers through personal interview with the help of pre-tested and structured schedules.

\section{Analytical; frame work}

Tabular analytical technique with help of percentages, averages and ratio were used to analyze and compute costs, returns, prices, sales etc. of producer-seller as well as different market functionaries. Analysis of primary and secondary data for estimation of trends of growth in area, production and productivity was estimated by the standard statistical analytical procedures as per the objectives of the present study. Cost of cultivation was computed by the standard statistical analytical procedures as per suggested by Acharya, 1997.

Trends of growth in area, production and productivity

To study the trends of growth in area, production and productivity of onion crop in Sikar district compound growth rate were worked out for 30 years data by using the formula:

$X_{t}=a b^{t}$

$\log X_{t}=\log a+t \log b$

Where;

$\mathrm{X}_{\mathrm{t}}=$ Area/production/productivity of onion crop in year " $\mathrm{t}$ "

$\mathrm{t}=$ Time element which takes the value $1,2,3$, ------, $n$

$\mathrm{a} \& \mathrm{~b}=$ Constant

\section{Compound growth rate}

Compound growth rate $(r)=(b-1) \times 100$

Where;

$r=$ growth rate in percentage

Student ' $t$ ' test was used to test the significance of the calculated compound growth rates by using the formula:
T
$\mathrm{T}=$
S.E. (r)
d. f. $=\mathrm{N}-2$

\section{Cost of cultivation}

In order to assess the profitability and economic viability in onion cultivation, various components of costs were estimated. The details of these cost concepts are given as follows:

\section{Operational cost $(\mathrm{O} . \mathrm{C}$. $)$}

It is variable cost, which varies with the level of production. It is expressed as:

O.C. $=$ Cost $\mathrm{A}_{1}-$ Land revenue - Depreciation

+ Family labour charges

Over Head Cost (O.H.C.)

It is fixed cost, which is incurred irrespective of the volume of production. It is expressed as:

O. H.C. $=$ Cost $\mathrm{C}_{2}-$ O.C.

\section{Cost of production (per quintal)}

Cost of production of onion was worked out using the formula: 
Cost of cultivation - value of by-product Cost of production (per quintal) $=$

Quantity of main product

\section{Results and Discussion}

Area, Production and Productivity of Onion in Sikar District

Table 1 reveals that the area under onion crop in Sikar district was 1135.0 hectares in 198190, which increased to 2166.1 hectares in 1991-2000 and further to 4555.5 hectares in 2001-10. Overall the area under onion crop had increased by 301.37 per cent in 2001-10 over 1981-1990.

The maximum rate of increase (328.59 per cent) was recorded in production while, minimum increase (6.72 per cent) was recorded in productivity of onion. It is further evident from the table 1 that the average area, production and productivity of Sikar district in the last 30 years were observed 2618.9 hectares, 25075.9 tons and $95.7 \mathrm{q} / \mathrm{ha}$, respectively.

Triennium Average Ending (TE) ofArea, Production and Productivity of Onion

In Sikar district, area under onion cultivation witnessed an increase of 245.3 per cent from 1339.3 ha during TE $1989-90$ to 4624.7 ha during TE 2009-10. Similarly, production of onion in the district witnessed an increase of 282.7 per cent from 14878.7 tones to 56939.3 tones during the corresponding period (Table 2). Productivity of onion has increased marginally by 7.6 per cent.

\section{Annual Compound Growth Rates in Area, Production and Productivity of Onion}

In Sikar district, the production of onion increased at compound growth rate of $18.65 \%$ per annum during the period -I (1981-1990), which was contributed both by the area $(4.70 \%)$ and productivity $(13.32 \%)$ but the contribution of productivity was more than that of area. During the period-II (1991-2000), the production of onion increased at the compound growth rate of 1.76 per cent per annum in spite of negative growth in productivity under the crop ( -4.56 per cent per annum). This was due to fact that higher positive growth in area $(6.62 \%)$ has not only compensated the decrease in productivity but also helped in increasing the production of the crop (Table 3). During the period-III (2001$10)$, compound growth rate for onion area $(2.71 \%)$, production $(9.66 \%)$ and productivity $(6.76 \%)$ worked out to be positive and maximum compound growth rate was recorded in production. The table further reveals that area, production and productivity of onion in the Sikar district in the overall period (1981-2010) have increased by 6.71, 8.11 and 1.32 per cent per annum. Production of onion in this period has increased due to increase in both the area and productivity but the maximum contribution was observed by the area.

Similarly Waghmare and Babar (1986), Pandita and Midmore (1994), Singh and Choudhary (1997), Kallo and Singh (2000), Malik et al., (2004) in their studies they also observed increasing trends in area, production and productivity of onion in various parts of the country including vegetables.

Total Costs and its Components in Production of Onion in Sikar District

This study of onion was based on 22.67, $34.67,29.33$ and 13.33 percent of small, semimedium, medium and large size sampled farmers, respectively in Sikar district. The average size of holding of the sampled respondents small, semi-medium, medium and large was 1.26 ha, 3.22 ha, 8.14 ha, and 13.72 ha, respectively. The sample farmers small, 
semi-medium, medium and large were found to grow onion over an area of 6.03, 8.07, 11.06 and 13.41 per cent, respectively in the total average size of the holding available with them (Table 4). The average bulb yield of onion was obtained by the small, semimedium, medium and large farmers was $267.2,275.1,286.1$ and 310.6 q/ ha, respectively. Total onion bulb yield was produced by the all 75 respondents (onion growers) was $13584.72 q$ from the 46.25 ha area.

The total cost incurred and their components in the cultivation of onion on sample farms in Sikar district are presented in table 5. On an average, total cost $\left(\operatorname{cost} \mathrm{C}_{2}\right)$ incurred in cultivation of onion was Rs.43263.3 per hectare. Among different size groups, it was Rs. 48851.6 on small; Rs. 43589.1 on semimedium; Rs. 39299.7 on medium and Rs. 41636.2 per ha on large sized farms. The total cost incurred in cultivation of onion was highest on small followed by semi-medium, large and medium sized farms. The total cost of cultivation consists of operational cost and overhead costs.

\section{Operational costs}

The operational cost of onion cultivation was higher than the overhead cost on all size groups of farms. The operational cost in absolute terms was lowest on large sized farms and highest on small sized farms in the study area on the sample farms. The overall operational cost of onion cultivation was Rs. 35881.29 (82.9 per cent of total cost) per hectare in Sikar district. It varied for different size groups of farms and was Rs. 40729.5 (83.4 per cent); Rs. 36536.7 (83.8 per cent); Rs. 32899.4 (83.7 per cent) and Rs. 32495.4 (78.0 per cent) of total cost per hectare on cultivation of onion on small, semi-medium, medium and large sized farms, respectively. Thus, the operational cost in cultivation of onion was highest on small sized farms and lowest on large sized farms (Table 5).

\section{Cost of cultivation}

\begin{tabular}{|l|l|}
\hline Cost $\mathbf{A}_{1}$ & $\begin{array}{l}\text { It is the actual paid cost by the farmers, cost of inputs such as value of hired } \\
\text { human labour + value of owned bullock labour + value of hired bullock labour } \\
\text { + value of owned machine labour + value of hired machine labour + value of } \\
\text { owned seed + value of purchased seed + value of owned farm yard manure }+ \\
\text { value of purchased farm yard manure + value of fertilizers + value of plant } \\
\text { protection chemicals + irrigation charges + land revenue + interest on working } \\
\text { capital + depreciation + miscellaneous expenses }\end{array}$ \\
\hline Cost $\mathbf{A}_{2}$ & Cost A1 + Rent paid for the leased-in land \\
\hline Cost $\mathbf{B}_{1}$ & Cost A1 + interest on value of owned fixed capital assets (excluding land) \\
\hline Cost $\mathbf{B}_{2}$ & Cost B1 + Rental value of owned land \\
\hline Cost $\mathbf{C}_{1}$ & Cost B1 + imputed value of family labour \\
\hline Cost $\mathbf{C}_{2}$ & Cost B2 + imputed value of family labour \\
\hline
\end{tabular}


Table.1 Area, Production and Productivity of Onion in Sikar District

\begin{tabular}{|l|c|c|c|c|}
\hline \multirow{2}{*}{ Period } & \multicolumn{4}{c|}{ Rajasthan } \\
\cline { 2 - 5 } & $\begin{array}{c}\mathbf{1 9 8 1 - 8 1} \\
\text { to } \\
1989-90\end{array}$ & $\begin{array}{c}\mathbf{1 9 9 0 - 9 1} \\
\text { to } \\
\mathbf{1 9 9 9 - 2 0 0 0}\end{array}$ & $\begin{array}{c}\mathbf{2 0 0 0 - 0 1} \\
\text { to } \\
\mathbf{2 0 0 9 - 1 0}\end{array}$ & $\begin{array}{c}\text { Per cent increased } \\
\text { in 2001-10 } \\
\text { over 1981-90 }\end{array}$ \\
\hline Area (ha) & 1135.0 & 2166.1 & 4555.5 & 301.37 \\
\hline Production (tones) & 9783.6 & 23512.7 & 41931.3 & 328.59 \\
\hline Productivity (q/ha) & 86.2 & 108.5 & 92.0 & 6.72 \\
\hline Average of the last 30 years & $\mathbf{2 6 1 8 . 9}$ & $\mathbf{2 5 0 7 5 . 9}$ & $\mathbf{9 5 . 7}$ & - \\
\hline
\end{tabular}

Source: Rajasthan Agricultural Statistics at a Glance 2010, Commissionrate of Agriculture, Rajasthan, Jaipur.

Table.2 Triennium Average Ending (TE) of Area, production and productivity of Onion in Rajasthan

\begin{tabular}{|l|c|c|c|c|}
\hline & TE 1989-90 & TE 1999-00 & TE 2009-10 & $\begin{array}{c}\text { Percentage } \\
\text { Change }\end{array}$ \\
\hline Area (ha) & 1339.3 & 2587.7 & 4624.7 & 245.3 \\
\hline Production (tones) & 14878.7 & 20365.3 & 56939.3 & 282.7 \\
\hline Productivity (q/ha) & 111.2 & 78.8 & 119.6 & 7.6 \\
\hline
\end{tabular}

Source: Rajasthan Agricultural Statistics at a Glance 2010, published by Commissionrate of Agriculture, Rajasthan, Jaipur.

Table.3 Annual compound growth rate in area, production and productivity of onion in Sikar

\begin{tabular}{|c|c|c|c|c|}
\hline District & Period & Area (\%) & Production (\%) & Productivity (\%) \\
\hline \multirow{3}{*}{ Sikar } & $1980-81$ to $1989-90$ & 4.70 & 18.65 & 13.32 \\
\cline { 2 - 5 } & $1990-91$ to $1999-00$ & 6.62 & 1.76 & -4.56 \\
\cline { 2 - 5 } & $2000-01$ to $2009-10$ & 2.71 & 9.66 & 6.76 \\
\cline { 2 - 5 } & $\mathbf{1 9 8 0 - 8 1}$ to 2009-10 & $\mathbf{6 . 7 1}$ & $\mathbf{8 . 1 1}$ & $\mathbf{1 . 3 2}$ \\
\hline
\end{tabular}

Table.4 Land holding and onion cultivation by sample farmers

\begin{tabular}{|c|l|c|c|c|c|c|}
\hline District & Category & $\begin{array}{c}\text { Sample } \\
\text { farmers }\end{array}$ & $\begin{array}{c}\text { Total } \\
\text { holding } \\
\text { (ha) }\end{array}$ & $\begin{array}{c}\text { Area } \\
\text { under } \\
\text { onion } \\
\text { crop (ha) }\end{array}$ & $\begin{array}{c}\text { Onion area as } \\
\text { \% of total } \\
\text { Holding }\end{array}$ & $\begin{array}{c}\text { Bulb yield } \\
\text { of onion } \\
\text { (q/ha) }\end{array}$ \\
\hline \multirow{2}{*}{ Sikar } & Small & $17(22.7)$ & $1.26(5.1)$ & 0.076 & 6.0 & 300.0 \\
\cline { 2 - 7 } & $\begin{array}{l}\text { Semi- } \\
\text { medium }\end{array}$ & $26(34.7)$ & $3.22(19.9)$ & 0.26 & 8.1 & 286.1 \\
\cline { 2 - 7 } & Medium & $22(29.3)$ & $8.14(42.5)$ & 0.90 & 11.1 & 275.1 \\
\cline { 2 - 7 } & Large & $10(13.3)$ & $13.72(32.6)$ & 1.84 & 13.4 & 267.0 \\
\hline & Overall & $\mathbf{7 5}(\mathbf{1 0 0})$ & $\mathbf{5 . 6 2}$ & $\mathbf{0 . 6 2}$ & $\mathbf{1 1 . 0}$ & $\mathbf{2 7 4 . 1 8}$ \\
\hline
\end{tabular}

*Figures in parenthesis are percentages of sample farmers / total holding. 
Table.5 Analysis of Cost of Cultivation of Onion on the Farms of Different Sizes in Sikar District of Rajasthan

\begin{tabular}{|c|c|c|c|c|c|c|}
\hline \multirow{3}{*}{$\begin{array}{c}\text { S. } \\
\text { No. }\end{array}$} & \multirow{3}{*}{ Particulars } & & & & & (Rs. /ha) \\
\hline & & \multicolumn{5}{|c|}{ Size Group } \\
\hline & & Small & $\begin{array}{l}\text { Semi- } \\
\text { medium }\end{array}$ & Medium & Large & Overall \\
\hline A. & \multicolumn{6}{|l|}{ Operational Cost } \\
\hline 1 & Machine Labour & $\begin{array}{c}3280.7 \\
(6.7)\end{array}$ & $\begin{array}{c}3610.2 \\
(8.3)\end{array}$ & $\begin{array}{c}3670.8 \\
(9.3)\end{array}$ & $\begin{array}{c}3590.7 \\
(8.6)\end{array}$ & $\begin{array}{c}3550.7 \\
(8.2)\end{array}$ \\
\hline 2 & Seed and Nursery raising cost & $\begin{array}{l}8190.7 \\
(16.8)\end{array}$ & $\begin{array}{c}7530.2 \\
(17.3)\end{array}$ & $\begin{array}{l}5416.7 \\
(13.8)\end{array}$ & $\begin{array}{c}5647.8 \\
(13.6)\end{array}$ & $\begin{array}{l}6809.0 \\
(15.7)\end{array}$ \\
\hline 3 & Manure & $\begin{array}{c}3343.7 \\
(6.8)\end{array}$ & $\begin{array}{c}2793.2 \\
(6.4)\end{array}$ & $\begin{array}{c}2071.9 \\
(5.3)\end{array}$ & $\begin{array}{c}3036.8 \\
(7.3)\end{array}$ & $\begin{array}{c}2738.9 \\
(6.3)\end{array}$ \\
\hline 4 & Fertilizers & $\begin{array}{c}2913.1 \\
(6.0)\end{array}$ & $\begin{array}{c}2845.8 \\
(6.5)\end{array}$ & $\begin{array}{c}2749.4 \\
(7.0)\end{array}$ & $\begin{array}{c}2529.2 \\
(6.1)\end{array}$ & $\begin{array}{c}2790.6 \\
(6.5)\end{array}$ \\
\hline 5 & PP Chemicals & $\begin{array}{c}1257.3 \\
(2.6)\end{array}$ & $\begin{array}{c}1122.7 \\
(2.6)\end{array}$ & $\begin{array}{c}1243.2 \\
(3.2)\end{array}$ & $\begin{array}{c}1205.4 \\
(2.9)\end{array}$ & $\begin{array}{c}1199.6 \\
(2.8)\end{array}$ \\
\hline 6 & Irrigation Charges & $\begin{array}{c}1960.6 \\
(4.0)\end{array}$ & $\begin{array}{c}1610.8 \\
(3.7)\end{array}$ & $\begin{array}{c}1597.6 \\
(4.1)\end{array}$ & $\begin{array}{c}1588.2 \\
(3.8)\end{array}$ & $\begin{array}{c}1683.2 \\
(3.9)\end{array}$ \\
\hline 7 & Interest on working capital & $\begin{array}{r}688.9 \\
(1.4)\end{array}$ & $\begin{array}{l}605.1 \\
(1.4)\end{array}$ & $\begin{array}{l}602.4 \\
(1.5)\end{array}$ & $\begin{array}{l}626.7 \\
(1.5)\end{array}$ & $\begin{array}{l}626.2 \\
(1.4)\end{array}$ \\
\hline \multirow[t]{2}{*}{8} & Human Labour & $\begin{array}{c}19094.5 \\
(39.1)\end{array}$ & $\begin{array}{c}16418.7 \\
(37.7)\end{array}$ & $\begin{array}{c}15547.4 \\
(39.6)\end{array}$ & $\begin{array}{c}14270.6 \\
(34.3)\end{array}$ & $\begin{array}{c}16483.2 \\
(38.1)\end{array}$ \\
\hline & Total Operational Cost & $\begin{array}{c}\mathbf{4 0 7 2 9 . 5} \\
(83.4)\end{array}$ & $\begin{array}{c}\mathbf{3 6 5 3 6 . 7} \\
(83.8)\end{array}$ & $\begin{array}{c}\mathbf{3 2 8 9 9 . 4} \\
(83.7)\end{array}$ & $\begin{array}{c}\mathbf{3 2 4 9 5 . 4} \\
(78.0)\end{array}$ & $\begin{array}{c}\mathbf{3 5 8 8 1 . 2 9} \\
(82.9)\end{array}$ \\
\hline B & \multicolumn{6}{|l|}{ Overhead cost } \\
\hline 1 & Interest on fixed capital & $\begin{array}{r}482.7 \\
(1.0)\end{array}$ & $\begin{array}{c}379.6 \\
(0.9)\end{array}$ & $\begin{array}{l}467.8 \\
(1.2)\end{array}$ & $\begin{array}{l}571.8 \\
(1.4)\end{array}$ & $\begin{array}{r}454.5 \\
(1.1)\end{array}$ \\
\hline 2 & $\begin{array}{l}\text { Depreciation on farm } \\
\text { implements and machinery }\end{array}$ & $\begin{array}{l}377.2 \\
(0.8)\end{array}$ & $\begin{array}{c}263.4 \\
(0.6)\end{array}$ & $\begin{array}{c}323.2 \\
(0.8)\end{array}$ & $\begin{array}{c}452.6 \\
(1.1)\end{array}$ & $\begin{array}{c}332.0 \\
(0.8)\end{array}$ \\
\hline 3 & Rental value of owned land & $\begin{array}{l}7253.2 \\
(14.8)\end{array}$ & $\begin{array}{l}6400.4 \\
(14.7)\end{array}$ & $\begin{array}{l}5600.3 \\
(14.3)\end{array}$ & $\begin{array}{c}8100.4 \\
(19.5)\end{array}$ & $\begin{array}{c}6585.7 \\
(15.2)\end{array}$ \\
\hline \multirow[t]{3}{*}{4} & Land revenue & $\begin{array}{c}9.0 \\
(0.02)\end{array}$ & $\begin{array}{l}9.0 \\
(0.02)\end{array}$ & $\begin{array}{c}9.0 \\
(0.02)\end{array}$ & $\begin{array}{l}16.0 \\
(0.04)\end{array}$ & $\begin{array}{c}9.9 \\
(0.02)\end{array}$ \\
\hline & Total overhead cost & $\begin{array}{l}\mathbf{8 1 2 2 . 1} \\
(16.6)\end{array}$ & $\begin{array}{c}\mathbf{7 0 5 2 . 4} \\
(16.2)\end{array}$ & $\begin{array}{c}\mathbf{6 4 0 0 . 3} \\
(16.3)\end{array}$ & $\begin{array}{c}9140.8 \\
(22.0)\end{array}$ & $\begin{array}{c}\mathbf{7 3 8 2 . 0} \\
(17.1)\end{array}$ \\
\hline & Total cost & 48851.6 & 43589.1 & 39299.7 & 41636.2 & 43263.3 \\
\hline
\end{tabular}

Note: Figures within the parenthesis for different components of operational cost and overhead cost are the percentages to the total cost. 
Table.6 Economics of Onion Production on the Farms of Different Sizes in Sikar District of Rajasthan

(Rs. /ha)

\begin{tabular}{|c|l|c|c|c|c|c|}
\hline S. No. & & \multicolumn{5}{|c|}{ Size Group } \\
\cline { 3 - 7 } & & Small & Semi-medium & Medium & Large & Overall \\
\hline $\mathbf{1}$ & Operational Cost & $\mathbf{4 0 7 2 9 . 5}$ & $\mathbf{3 6 5 3 6 . 7}$ & $\mathbf{3 2 8 9 9 . 4}$ & $\mathbf{3 2 4 9 5 . 4}$ & $\mathbf{3 5 8 8 1 . 3}$ \\
& & $(83.4)$ & $(83.8)$ & $(83.7)$ & $(78.0)$ & $(82.9)$ \\
\hline $\mathbf{2}$ & Overhead Cost & $\mathbf{8 1 2 2 . 1}$ & $\mathbf{7 0 5 2 . 4}$ & $\mathbf{6 4 0 0 . 3}$ & $\mathbf{9 1 4 0 . 8}$ & $\mathbf{7 3 8 2 . 0}$ \\
\hline & & $(16.6)$ & $(16.2)$ & $(16.3)$ & $(22.0)$ & $(17.1)$ \\
\hline $\mathbf{3}$ & Cost $\mathrm{A}_{1}$ & 28631.7 & 25081.2 & 24231.2 & 26164.1 & 25781.0 \\
& & $(58.6)$ & $(57.5)$ & $(61.7)$ & $(62.8)$ & $(59.6)$ \\
\hline $\mathbf{4}$ & Cost $\mathrm{A}_{2}$ & 28631.7 & 25081.2 & 24231.2 & 26164.1 & 25781.0 \\
& & $(58.6)$ & $(57.5)$ & $(61.7)$ & $(62.8)$ & $(59.6)$ \\
\hline $\mathbf{5}$ & Cost $\mathrm{B}_{1}$ & 29114.4 & 25460.8 & 24699.0 & 26735.9 & 26235.5 \\
& & $(59.6)$ & $(58.4)$ & $(62.8)$ & $(64.2)$ & $(60.6)$ \\
\hline $\mathbf{6}$ & Cost $\mathrm{B}_{2}$ & 36367.6 & 31861.2 & 30299.3 & 34836.3 & 32821.2 \\
& & $(74.4)$ & $(73.1)$ & $(77.1)$ & $(83.7)$ & $(75.9)$ \\
\hline $\mathbf{7}$ & Cost $\mathrm{C}_{1}$ & 41598.4 & 37188.7 & 33699.4 & 33535.8 & 36677.7 \\
& & $(85.2)$ & $(85.3)$ & $(85.7)$ & $(80.5)$ & $(84.8)$ \\
\hline $\mathbf{8}$ & Cost $\mathrm{C}_{2}$ & 48851.6 & 43589.1 & 39299.7 & 41636.2 & 43263.3 \\
& & $(100.0)$ & $(100.0)$ & $(100.0)$ & $(100.0)$ & $(100.0)$ \\
\hline & Cost of Production (Rs./q) & $\mathbf{1 8 2 . 8}$ & $\mathbf{1 5 8 . 4}$ & $\mathbf{1 3 7 . 4}$ & $\mathbf{1 3 4 . 1}$ & $\mathbf{1 5 3 . 8}$ \\
\hline & Returns & & & & & \\
\hline $\mathbf{1}$ & Gross Return & 122912.0 & 126546.0 & 131606.0 & 142876.0 & 129383.9 \\
\hline $\mathbf{2}$ & Return over Operating Cost & 82182.5 & 90009.3 & 98706.6 & 110380.6 & 93502.6 \\
\hline $\mathbf{3}$ & Net Income & 74060.4 & 82956.9 & 92306.3 & 101239.8 & 86120.6 \\
\hline $\mathbf{4}$ & Family Labour Income & 86544.4 & 94684.8 & 101306.7 & 108039.7 & 96562.7 \\
\hline $\mathbf{5}$ & Farm Business Income & 94280.3 & 101464.8 & 107374.8 & 116711.9 & 103602.9 \\
\hline $\mathbf{6}$ & Returns Per Rupee of Expenditure & $\mathbf{2 . 5 2}$ & $\mathbf{2 . 9 0}$ & $\mathbf{3 . 3 5}$ & $\mathbf{3 . 4 3}$ & $\mathbf{2 . 9 9}$ \\
\hline & Net & & & \\
\hline
\end{tabular}

Note: Figures within the parenthesis for different cost groups are the percentages to the total cost.

Human labour was the major component of operational cost on sample farms as it alone accounted for 38.1 per cent (Rs.16483.2) of the total cost. The cost on manures, machine, labour, fertilizers, plant protection chemicals, seed and nursery raising cost and irrigation charges together accounted for 43.4 per cent of the total cost.

Large and small sized farms incurred more on cost for manure compared to other size groups. Vermi-compost/poultry manure being costlier was used by the large and small sized farmers, whereas semi-medium and medium sized farmers used FYM only. Further, in general, machine, labour cost increased in absolute as well as in terms of per cent of the total cost with the increase in size small to medium size of holding (6.7-9.3 per cent). Seed and nursery raising cost was highest (17.3 per cent) on semi-medium sized farms and lowest on large sized farms (13.6 per cent).

\section{Overhead costs}

On an average, the total overhead cost in cultivation of onion in Sikar district was Rs. 
7382.0 (17.1 per cent) per hectare. On different size groups, it was Rs. 8122.1 (16.6 per cent) on small; 7052.4 (16.2 per cent) on semi-medium; 6400.3 (16.3 per cent) on medium and 9140.8 (22.0 per cent) on large sized farms. The overhead cost in cultivation of onion was highest on large sized farms followed by small, semi-medium and medium sized farms. Rental value of owned land was the main item in the overhead cost as it accounted for 15.2 per cent of the total costs. The items viz., interest on fixed capital and depreciation together accounted 1.9 per cent of the total cost of cultivation. Land revenue accounted for negligible share to the total cost of cultivation (Table 5).

\section{Cost Groups and Returns from Cultivation of Onion in Sikar District}

\section{Cost groups}

It is evident from the table 6 that the overall $\operatorname{cost} A_{1}, \&$ Cost $A_{2}$, cost $B_{1}$, Cost $B_{2}$ and cost $\mathrm{C}_{1}$ were Rs.25781.0 (59.6 per cent); Rs.26235.5 (60.6 per cent); Rs. 32812.2 (75.9 per cent) and Rs. 36677.7 (84.8 per cent) per hectare on different sized sampled farms. Cost $A_{2}$ was same as cost $A_{1}$ on all size groups of farms because none of the sampled farmers leased in any land for cultivation of onion in the study area. The overall cost of production of onion was Rs. 153.8 per quintal. It was Rs. 182.8, Rs. 158.4, Rs. 137.4 and Rs. 134.1 on small, semi-medium, medium and large sized farms, respectively. The cost of production per quintal of onion was highest on small and lowest on large sized farms (Table 6).

\section{Returns}

On an average gross income received by farmers of Sikar district from cultivation of onion was Rs. 129383.9 per hectare. On different size groups of farms, it was Rs. 122912.0 on small, Rs. 126546.0 on semi- medium, 131606.0 on medium and Rs. 142876.0 on large sized farms. The average return over operating costs, net income, family labour income and farm business income per hectare of onion cultivation were Rs. 93502.6, Rs. 86120.6, Rs. 96562.7 and Rs. 1030602.9, respectively on sampled farms (Table 6).

The return per rupee of expenditure from onion cultivation was Rs. 2.52 on small, Rs. 2.90 on semi-medium, Rs.3.35 on medium and Rs. 3.43 on large sized farms with an overall of Rs. 2.99 .

Table 6 further depicts that the income measures viz., gross return, return over operating cost, net return, family labour income and farm business income were highest on large sized farms followed by medium, semi-medium and small sized farms in the Sikar district.

The results indicate that in Sikar district area, production and productivity of onion in the overall period (1981-2010) have increased by $6.71,8.11$ and 1.32 per cent per annum. Production of onion in this period has increased due to increase in both the area and productivity but the maximum contribution was observed by the area. The average bulb yield of onion was obtained by the small, semi-medium, medium and large farmers was 267.2, 275.1, 286.1 and $310.6 \mathrm{q} / \mathrm{ha}$, respectively. Total onion bulb yield was produced by the all 75 respondents (onion growers) was $13584.72 \mathrm{q}$ from the 46.25 ha area. On an average, total cost $\left(\operatorname{cost} \mathrm{C}_{2}\right)$ incurred in cultivation of onion was Rs.43263.3 per hectare. Among different size groups, it was Rs. 48851.6 on small; Rs. 43589.1 on semi-medium; Rs. 39299.7 on medium and Rs. 41636.2 per ha on large sized farms. The total cost incurred in cultivation of onion was highest on small followed by semimedium, large and medium sized farms. The 
operational cost in cultivation of onion was highest on small sized farms and lowest on large sized farms. The overhead cost in cultivation of onion was highest on large sized farms followed by small, semi-medium and medium sized farms. The cost of production per quintal of onion was highest on small and lowest on large sized farms. The study concluded that the large size group of farms obtained the largest amount of profit in the study area. The results further revealed that the the income measures viz., gross return, return over operating cost, net return, family labour income and farm business income were highest on large sized farms followed by medium, semi-medium and small sized farms in the Sikar district. Since increase in production of onion is must for meeting domestic requirement and for increasing income of farmers so, it is necessary to identify the thrust areas of development and prioritize the same for effective achievement of the goal at a faster rate.

\section{References}

Acharya, S.S. (1997). Agricultural Price Policy and Development: Some facts and Emerging issues. Indian Journal of Agricultural Economics, 52(1): 6.

Anonymous (2010). Rajasthan Agricultural Statistics at a Glance for the year 200910. Statistical Cell, Commissionrate of Agriculture, Rajasthan, Jaipur.

Anonymous (2017). Statistics. Horticulture Division, Ministry of Agriculture. Government of India.

Bijarnia, S.K. (1998). An Economic Analysis of Onion Cultivation in Jaipur District of Rajasthan. M.Sc. (Ag.), Agril. Economics, Thesis (unpublished), RAU, Campus - Jobner, Rajasthan.

Dangat, S.D., Pagire, B.V. and Ratnaparkhe, A.N. (1989).Economics of production and marketing of onion in Maharashtra.
Indian Journal of agricultural Marketing, Seminar Special Issue, September, p.119.

Gupta, R.K. and Hiralal (1984). The Costs Benefit Analysis of Onion Cultivation for Hilly regions. Indian Horticulture, 30(2): 169 .

Jat, J.P. (2000). Economic Analysis of Onion Cultivation in Jaipur District of Rajasthan. M.Sc. (Ag.), Agril. Economics, Thesis (unpublished), RAU, Campus- Jobner, Rajasthan.

Kallo, G. and Singh Kirti (2000). Emerging Scenario in vegetable Research. Periodicals and Book Publishing House, India; 326.

Kulkarni, D.N. (2011). Export Marketing and Processing of India. In: National Symposium on Alliums: Current Scenario and Emerging Trends, March 12-14, 2011, Pune, Maharashtra. pp. 99108.

Lawande, K.E. and Vijay Mahajan (2011). Innovations in Population Improvement in Onion. In: National Symposium on Alliums: Current Scenario and Emerging Trends, March 12-14, 2011, Pune, Maharashtra. pp. 11-28.

Malik, D.P., Kumar, Sanjay and Hooda, B.K. (2004). An Economic Analysis of Production and Export of Onion in India. Agricultural Marketing, AprilJune, p.12-19.

Manjunathagowda D.C. et al., (2015). Prosperity of Onions in India. Popular Kheti, 3(3):33-39.

Mishra, S.N., Tripathi, S. and Prusty, B.K. (1995). Production and Marketing of Onion in Kalahandi District of Orissa.Indian Journal of Agricultural Marketing, Conference Special, p.167.

Mohapatra, S.C. (1999). Production and Marketing of Onion in Bolangir District of Orissa. Indian Journal of Agricultural Marketing, 13(1): 40-43. 
Pandita, M.L. and Midmore, D.J. (1994). Studies of Allium Production and Research in India. Acta Horticulture, No.358: 79 -86.

Pant, D.C. and Singh Diwakar (1987). Economics of Some Vegetables, Agronomical Crops and Livestock. M.Sc. (Ag.), Thesis (unpublished), Directorate of Extension Education, Rajasthan Agricultural University, Bikaner, Campus-Udaipur.

Patil, B.L., Basavarja, H., Hosmani, S.B. and Mudinamni, S.M. (1989). Scale of Finance and Cost of Cultivation for Selected Vegetable Crops in Bijapur District. Financing Agriculture, 21(1):11-13.

Patil, S.D. (1975). Economics of Production and Marketing of Onion in Khed Tehsil of Pune District of Maharashtra. M.Sc. (Ag.) Thesis (unpublished), Mahatma Phule Krishi Vishwavidyalaya, Rahuri (Maharashtra).

Sekhon, M.K. and Kaur, Manjeet (2004). Role of Small Farmers in Diversification of Punjab Agriculture with Vegetables. Indian journal of Agricultural Marketing, 18 (1): 80-88.

Shah, Deepak (1999). Production and Marketing of Onion in Bolanger District of Orissa. Indian Journal of agricultural Marketing, 13 (3): 11-19.

Shyamasunder, M.S. and Achoth, Lalith (1996). Price Spread in Marketing of Irrigated Onion in Chickballapur Taluka of Kolar District. Indian journal of Agricultural Marketing, 10 (1): 52-57

Sidhu, R.S., Sanjay Kumar, Kamal Vatta and Parmindar Singh (2010). Supply Chain Analysis of Onion and Cauliflower in Punjab. Agricultural Economics Research Review, 23: 445-453.

Singh, S.N. and Choudhary, P.K. (1977). Production and Marketing of Onion in Rajasthan. Indian journal of Agricultural Marketing, 15 (3): 120126.

Verma, A.R., Rajput, A.M. and Patidar, R.S. (2004). Economic Analysis of Production Use Efficiency and Constraints of Onion in Indore District of Madhya Pradesh. Agricultural Marketing, January-March, 2004:2231.

Waghmare, R.E. and Babar, V.S. (1986). Performance of Onion in Maharashtra. Journal of Maharashtra Agricultural University, 11(3): 351-354.

Weinberger, K. and Lumpkin, Thomas A. (2006). High Value Agricultural Products in Asia and the Pacific for the Small Holder Farmers: Trend, Opportunities and Research Priorities. Proceeding of the workshop "How Can the Poor Benefit from the Growing Markets for High Value Agricultural Products," held at CIAT, Cali, Cambodia and published by World Vegetable Centre (AVRDC).

\section{How to cite this article:}

Swati Sharma. 2019. Economics of Onion Production in Sikar District of Rajasthan. Int.J.Curr.Microbiol.App.Sci. 8(07): 1440-1450. doi: https://doi.org/10.20546/ijcmas.2019.807.172 